\title{
ERNEST THOMPSON SETON'S SASKATCHEWAN HOMESTEAD
}

\author{
3y C. STUART HOUSTON, 863 University Drive, Saskatoon, Sask.
}

Three generations have been raised on Ernest Thompson Seton's animal stories. My ather remembers that the stories of Raggylug, Redruff, Silverspot and Lobo were mong the first stories his mother read to him. My mother read the same stories to me nd I in turn read them to my four children. Yet none of us then appreciated that eton had homesteaded in what is now Saskatchewan, just 50 miles from Yorkton. "ew naturalists have realized that Seton's nest of the Philadelphia Vireo, the first uthenticated nest of the species ever reported, is a Saskatchewan, rather than a Manitoba, record.

Born Ernest Evan Thompson in jouth Shields, at the mouth of the River Tyne, on 14 August, 1860, his amily emigrated when he was 6 to a ackwoods farm near Lindsay, west of Peterborough, Ontario. His father, a hearly bankrupt shipowner, was no nore successful as a farmer, and in 870 the Thompsons moved into oronto. Ernest attended Toronto Collegiate and then the Ontario School if Art, where he won the gold medal. After $2-1 / 2$ years studying art in Lonlon, England, he returned to Canada th the fall of 1881 , having assumed the ncient family name of Seton on his 1st birthday.

On his return to Toronto, two events reatly influenced his future. First, he purchased a copy of Coues' Key to North American Birds. Second, he pecame a friend of William Brodie, r., and fell under the influence of Willie's father, Dr. William Brodie, vho later gave up dentistry and ecame Ontario's first provincial haturalist as well as biologist at the Ontario Museum. Dr. Brodie told feton that he should keep a daily joural. His apt pupil began at once and he first entry was: "Toronto, Ont., Monday, 13 Nov. 1881: Saw three obins over the White Bridge."

Early in 1882 , Seton left Toronto on farmer's train for Manitoba, via St. aul, Minnesota, with his friend Willie prodie. On 3 April, Seton reached his brother's homestead, less than a mile north of the temporary station of De Winton, which was replaced by the permanent station of Carberry, nearly 2 miles further west, the next year.

Seton later said that "my real journal and my real life were begun in Manitoba." Those were the days of free homestead land and Seton wished to file for a homestead. He made a long trip in May south to Turtle Mountain with his two brothers, Arthur and Charlie, and another long trip in July to Russell and the Upper Assiniboine with Arthur and Walter, another brother, both times without finding a homestead that met his requirements. Meanwhile, his observations and experiences around Carberry were faithfully recorded and later formed the basis for the story of "Bingo" in Wild Animals I have Known, and for his book, The Trail of the Sandhill Stag.

In March, 1883, Seton had surgical repair of a hernia in Chicago. In June, near Carberry, he found the first nest ever reported of the Connecticut Warbler, duly reported in Vol. 1 of The Auk in 1884. A. C. Bent in his Life Histories of North American Wood Warblers (1953) gave Seton full credit and stated that this was the only documented nest of the species for another 40 years, though Bent overlooked John Macoun's nest found in the same swamp south of Carberry, 12 June 1896. 


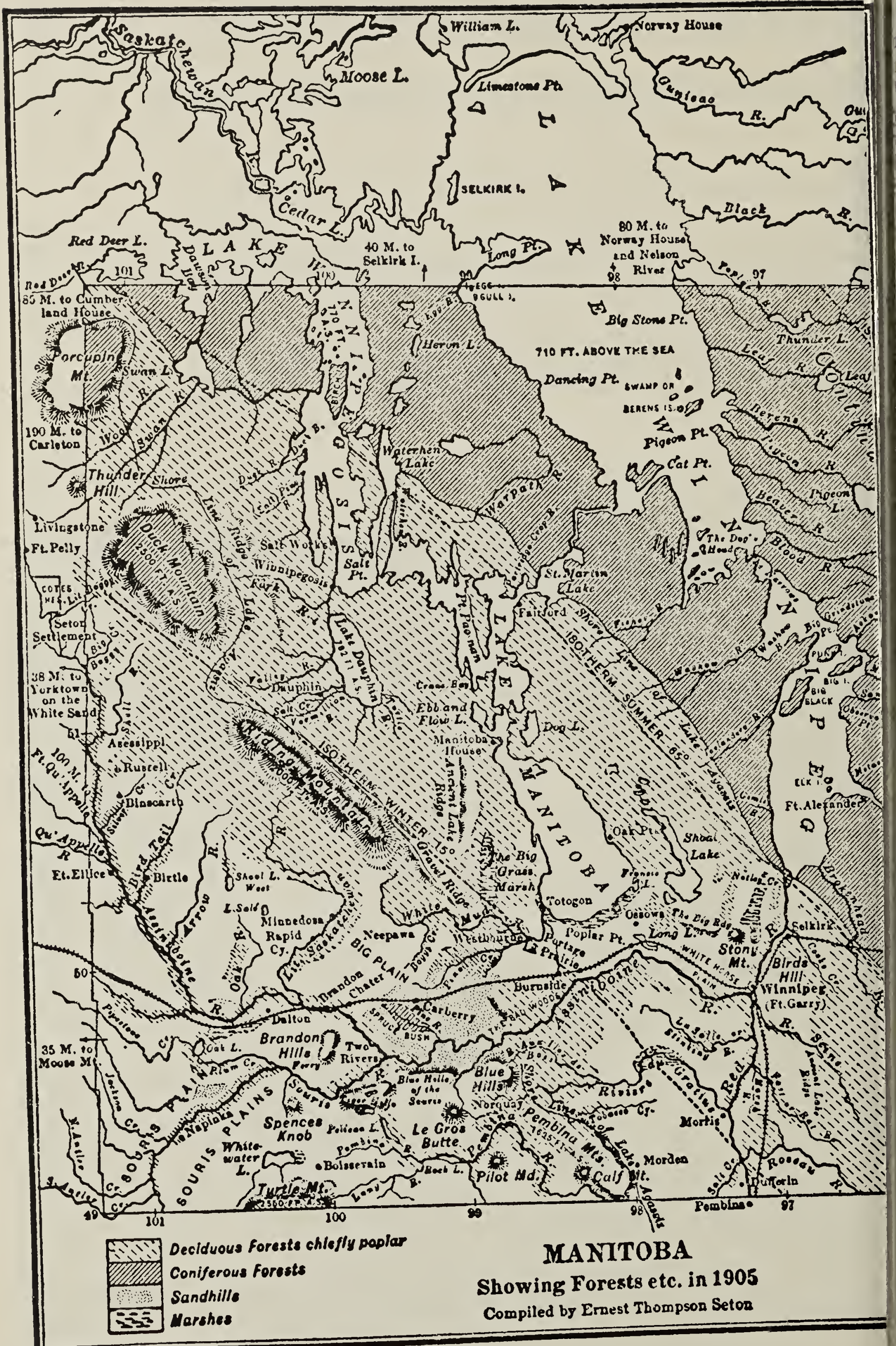

From Ecology of the aspen parkland of western Canada in relation to land use.

R. D. Bird, 196 
Seton's young friend, Willie Brodie, unfortunately drowned when his canoe upset on the Upper Assiniboine in May, 1883, but in July and August that year Seton was stimulated by a long visit from a young naturalist from England, R. Miller Christy. On 8 and 9 August, the two men together visited the Criddle family, who had settled at Aweme, near the Assiniboine southeast of Brandon, the previous year. Seton and Christy gave lessons in trapping and bird skinning to the Criddle sons, Norman and Stuart, both of whom became well known naturalists.

Seton's third trip to seek a homestead began with two friends, John Duff and George Richardson, on 1 October 1883. They passed Shoal Lake village 4 October and reached Big Boggy Creek on 9 October, crossing the western boundary of Manitoba which had been extended to its present location only 2 years before. On 11 October, Seton chose his homestead quarter and the adjacent pre-emption quarter on the south half of Section 36, Township 28, Range 31 west of the Principal Meridian, in the District of Assiniboia, Northwest Territories. He chose the north half of Section 36 for his brother, Arthur. This section is just a mile southwest of the present hamlet of Runnymede, Saskatchewan, 1 mile east of the Assiniboine River valley, and less than 4 mile west of a parallel coulee, now officially named Seton Coulee in his honor. Obviously some geographer knew more of Seton's history than any of the local residents we talked to when all three Houston generations nade a pilgrimage to the Seton lomestead in 1975.

Seton always spoke of this homestead as being on the edge of the Duck Mountains, which indeed were only 4 miles to the north. That fall he recorded a Great Horned Owl hooting at his homestead and a Peregrine Falcon in migration. He did not visit Madge Lake, 12 miles away, but he did visit the Hudson's Bay Company post of Fort Pelly, on the Assiniboine River 24 miles northwest of his homestead, on 16 October. He registered his homestead and preemption at the land office at Birtle on 25 October and reached Carberry on 29 October.

Seton spent 4-1/2 months working as an artist in New York City that winter and did not return to Carberry until 28 April, 1884. He stayed with his brother Arthur until 2 June, when they set out for their homestead by horse and wagon. On 4 June they passed through Shoal Lake village and on 6 June they travelled from Binscarth to Assessippi on the Shell River, where a new mill and hotel had attracted 300 pairs of Cliff Swallows beneath their eaves. They arrived 8 June at the homestead and the next day dug their well, 2 feet wide and only 4 feet deep, near the bank of a small stream, from which the well received its water. This was the day that Seton discovered the Philadelphia Vireo nest. He waited until 13 June, when the female began incubating her four eggs, before collecting her to confirm the identification. This nest, 10 feet from the ground in a willow, was either on the homestead or very nearby. A. C. Bent in his Life Histories of North American Wagtails, Shrikes, Vireos and Allies (1950) told how this was the only nest known for another 19 years, but incorrectly gave the locality as Manitoba.

On 10 June, 1884, Ernest and his brother Arthur began cutting and hauling timbers for their claim shanty. Fourteen logs 8 feet long and another 14 logs 12 feet in length made the 8 - by 12-foot claim shanty. The cutting and trimming of these logs required until 14 June and on 17 June they had the shanty finished with roof and door. The spaces between the logs were blocked with split strips of wood, nailed in and plastered over from both sides with tempered mud. The roof was made of prairie hay one foot deep, topped with 6 inches of clay. Finally, he carved in the lintel over the door: "E. T. Seton, 1884".

Seton used well what little spare time he had. On 8 June, 1884, he found the nest and eggs of a Redstart, studied the Yellowthroat in low damp thickets 


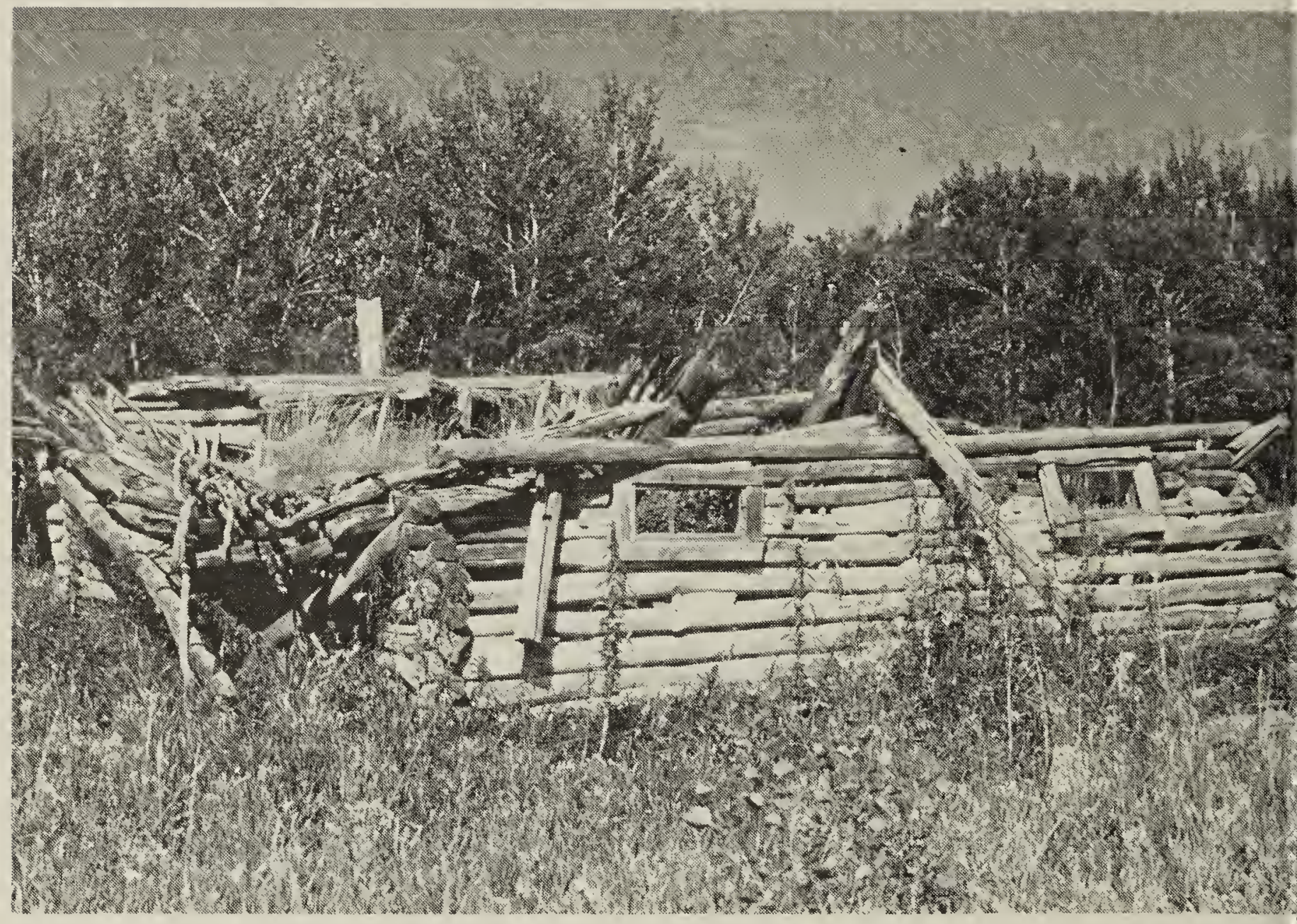

This log structure is near the centre of the southern edge of Seton's homestead section, bu was probably constructed at least 20 years after Seton's homestead cabin. 1975.

C. S. Housto

and recorded White-rumped Sandpipers. On 10 June, he collected a male Myrtle Warbler and identified the Black-and-white Warbler and the Solitary Vireo. On 11 June, a young Gray Jay was collected and a Tennessee Warbler was seen, the latter to be collected the following day together with a male Olive-sided Flycatcher. Also on 12 June, he shot a Western Wood Pewee, frequenting the open woods and willow thickets, while on 14 June, he collected an Eastern Wood Pewee from the thicker woods higher on the slopes of Duck Mountain. On the latter day he also found one or two pairs of Connecticut Warblers resident in a nearby tamarack swamp and found three or four nests of the Claycolored Sparrow in 1 or 2 hours.

Seton found a nest of the Rednecked Grebe at a small lake and a
Ruffed Grouse gave a spirited distrac tion display, though he found neithe nest nor young. He listed the Buffle head, Sora Rail, House Wren, Cat bird, Nashville and Chestnut-sider Warblers, Common Grackle and th Leconte's, White-throated and Son Sparrows as breeding, with the Fo Sparrow as "evidently breeding." H also recorded the Horned Grebe Turkey Vulture, Sharp-tailed Grouse Common Snipe, Great Horned Ow Eastern Kingbird, Yellow-bellie Flycatcher, "Acadian Flycatcher" [a error, though a specimen was collec ted; perhaps a Traill's], Short-bille Marsh Wren, Veery, Cedar Waxwing Solitary Vireo, Warbling Virec Mourning Warbler and Baltimor Oriole. He was most surprised not $t$ find a single junco during June. $H$ listed the Red-throated Loon in $h$ 1886 list, but evidently recognized $h$ 
Manitoba, which was published by the Smithsonian Institution in late 1890 , after he had left for Paris to continue his studies in Art.

Seton's last significant sojourn was in the summer of 1892 after his return from Paris. His brother Arthur was no longer on the farm, but Ernest stayed at a boarding house in Carberry from 4 June to 12 September, noting the changes in bird life that had occurred as the country became intensively farmed. His favorite body of water, Shaska-water, named for his Indian friend, had been drained, aspens were springing up everywhere as the prairie fires were controlled, and the evergreens in the sandhills south of Carberry had filled in the gaps caused by previous fires. He reported that the beautiful prairie flowers had been replaced by Canada thistle, Russian thistle and tumbleweeds along the fence lines. The Upland Sandpiper, the Chestnut-collared Longspur and the Sprague's Pipit were gone, as the prairie had succumbed to the plough. The Thirteen-striped Ground Squirrel had greatly decreased, while the Richardson's Ground Squirrel had increased. Sharp-tailed Grouse were restricted to the woods, but the new immigrant from Minnesota, the Pinnated Grouse or Greater Prairie Chicken, was now everywhere.

Seton described the above changes in a paper published in The Auk early in 1893. Meanwhile, he helped gather specimens of birds to be shown at the great Chicago Fair of 1893 and in return persuaded Premier Thomas Greenway that he should be appointed as official naturalist to the government of Manitoba. The interview took place in Toronto 19 September, 1892 and the writ appointing him as naturalist lkindly copied by Ardythe McMaster], and signed by Greenway as Minister of Agriculture and Immigration, was dated 4 November, 1892. Note that the date for this appointment given in the introduction to the 1975 reprinting of Birds of Manitoba was 9 years prematurel. The title carried no pay, but was used proudly by Seton for many years.
The story of Seton's name is very complicated. His eight articles in The $A u k$ in 1884,1885 and early 1886 were under the name of Ernest Evan Thompson Seton. As stated above, this was the name he had adopted on his 21 st birthday, 14 August, 1881, completing the "necessary formalities" and assuming the "full and proper legal style" only on 1 February 1883. Later, in the brief addendum to his "Birds of Western Manitoba" in the October 1886 issue of The $A u k$, he reverted to the name of Ernest E. Thompson and stated that: "Hitherto I have written under the assumed name of 'Seton': henceforth I shall write and be known only by my true name [Ernest $E$. Thompson]." Yet to confuse his readers further, his two articles on new species of caribou in the Ottawa Naturalist in 1899 and 1900 were under "Ernest Seton-Thompson."

In his autobiography, he explains that he adopted the nom de plume of 'Seton-Thompson' to please his mother and that on her death in 1897 he was free to resume "what was really my legal name [Seton]." On 28 November, 1891, the Supreme Court of New York rendered its decision on this now complex and knotty question and decreed that 'Seton-Thompson' was a nom de plume and that 'Seton' was his legal name.

As far as we know, from the book, By $A$ Thousand Fires, published by his second wife after his death, Seton's last visit to Manitoba was during a lecture tour in 1924 . He went by car 50 miles from Ninette to Morden and "did not see one wild living creature". On the train between Swan River and Gladstone, he overheard four men talking of the 400 Sharp-tailed Grouse they had shot the previous year and wondering why grouse were scarce that year. Grandiloquently, Seton then told the Canadian Club in Ottawa: "We have desolated our heritage, absolutely devastated these wonderful wilds. We have robbed our children. We have robbed our country." 